\title{
ANALISIS KETERKAITAN INSTRUMEN KEBIJAKAN MONETER, DEFISIT ANGGARAN, DAN NERACA PEMBAYARAN INDONESIA TAHUN 2002 - 2017
}

\author{
Orlandio Jeremy ${ }^{1}$, Banatul Hayati ${ }^{2}$
}

Departemen IESP Fakultas Ekonomika dan Bisnis Universitas Diponegoro

Jl. Prof. Soedharto SH, Tembalang Semarang

orlandiojeremy@gmail.com

\begin{abstract}
This study aims to analye the linkages of monetary policy instruments, budget deficit and balance of payments with VECM method. This study used secondary data from 2002 quarter I to 2017 quarter IV.

The result found one-way interaction between open market operation with Indonesian balance of payments. Money supply has two-way causality relationship with budget deficits and minimum reserve requirement. The exogenous variable which are BI rate and open market operation affected Indonesian's balance of payments with positive correlation, while the minimum reserve requierment significantly affect Indonesian's balance of payments with negative correlation. Impulse response found shock of money supply respond to balance of payments positive in the fourth period.

This result show that Indonesia's balance of payments is a monetary phenomenon. So monetary policy instruments BI rate, minimum reserve requirement and open market operation can be used to maintain the stability of Indonesia's balance of payment.
\end{abstract}

Keywords: Instrument of Monetary Policy, Budget Deficit, Balance of Payment, Vector Error Correction Model (VECM)

\section{PENDAHULUAN}

Permasalahan yang sering terjadi di negara berkembang adalah tingginya tingkat pengangguran dan inflasi, hal ini dikarenakan masih adanya external imbalance. External imbalance disebabkan oleh permintaan yang tinggi tidak sebanding dengan supply yang berakibat meningkatnya impor sedangkan ekspor tetap. Dengan terjadinya hal tersebut maka current account pada neraca pembayaran akan terkena dampak buruknya (Maipita 2012).

Menurut Nwanosike. et al., (2017) Neraca Pembayaran (balance of payment) adalah laporan berkala yang merangkum aliran transaksi ekonomi dengan asing. Neraca pembayaran memiliki sifat dasar yaitu balance, keseimbangan neraca 
pembayaran tetap terjadi akan tetapi untuk menyeimbangkannya harus ditutupi dengan utang luar negeri ataupun dengan cara penjualan aset negara yang meningkatkan cadangan devisa. Transaksi yang tercatat dalam neraca pembayaran adalah neraca transaksi berjalan (current account) dan neraca transaksi modal dan finansial (capital and financial account).

Menurut Departemen Statistik Bank Indonesia (2014) transaksi berjalan mencakup ekspor dan impor barang, jasa, pendapatan primer, dan pendapatan sekunder. Ketika ekspor dikurangi impor memiliki nilai negative maka dapat disimpulkan transaksi berjalan mengalami defisit, sebaliknya apabila hasil penjumlahan ekspor dikurangi impor memiliki nilai positif maka disimpulkan transaksi berjalan mengalami surplus. Sementara itu, transaksi Modal (capital account) berupa transfer modal (capital transfer) dan transaksi finansial (financial account) berupa transaksi direct investment, portfoloio investment, financial derivatives, dan investasi lainnya. Aliran modal masuk (capital inflow) dimana aliran modal mengalir ke domestic atau bisa juga disebut capital import, sebaliknya aliran modal keluar (capital outflow) dimana aliran modal mengalir keluar dari negara domestic atau bisa juga disebut capital export.

Defisit neraca pembayaran dalam jangka panjang menimbulkan dampak negative yaitu devisa yang semakin lama semakin habis yang seharusnya digunakan untuk mengimpor barang, jasa dan membayar utang denga bunganya. Sebaliknya surplus neraca pembayaran yang tidak normal memiliki dampak negative dalam jangka panjang dikarenakan terindikasinya penumpukan devisa yang berarti tidak adanya efisiensi dari pemakaian devisa, hal ini berpengaruh pada kemakmuran masyarakat.

Pendekatan moneter, pendekatan absorpsi, dan pendekatan elasitisitas merupakan pendekatan yang digunakan untuk mempelajari Balance of Payment. Pendekatan Keynesian seringkali disebutkan yang merupakan pendekatan elastisitas dan absorbi.

Secara teoritis menurut Mundell-Fleming kebijakan moneter mempengaruhi neraca pembayaran melalui mobilitas modal maupun mobilitas barang dan jasa. Kebijakan moneter ekspansif maupun kontraktif menyebabkan terjadinya depresiasi/apresiasi dan berdampak pada harga relative barang dan jasa, berimplikasi pada transaksi domestik dan luar negeri sehingga dengan adanya perubahan pada ekspor impor maka akan terjadi perubahan komposisi pada neraca perdagangan. Kebijakan moneter ekspansif maupun kontraktif juga mempengaruhi aliran modal dari sisi selisih suku bunga domestic dan luar negeri. Perbedaan tingkat bunga internasional dan domestic menyebabkan adanya aliran keluar masuknya modal dari suatu negara lain (Mankiw 2006).

Secara teori kebijakan fiscal mempengaruhi neraca pembayaran melalui transaksi berjalan. Dengan menggunakan model Mundell-Fleming defisit anggaran menyebabkan kenaikan suku bunga yang menyebabkan terjadinya aliran modal masuk dikarenakan adanya selisih suku bunga internasional dan domestic. Maka dari itu peningkatan defisit anggaran akan mendorong impor, hal tersebut berimplikasi pada 
defisit perdagangan yang pada akhirnya mempengaruhi ketidakseimbangan transaksi berjalan yang merupakan komponen dari neraca pembayaran (Nizar 2012).

Secara empiris studi yang dilakukan oleh Imoisi et al. (2013) menemukan bahwa jumlah uang beredar, tingkat suku bunga, dan nilai tukar mempengaruhi neraca pembayaran Nigeria tahun 1980-2010. Hasil dari penelitian tersebut mengemukakan bahwa jumlah uang beredar memiliki korelasi positif dan mempengaruhi neraca pembayaran secara signifikan. Tingkat suku bunga memiliki korelasi negative dengan neraca pembayaran dan memiliki kontribusi yang signifikan. Hanya nilai tukar yang tidak signifikan mempengaruhi neraca pembayaran Indonesia, akan tetapi berkorelasi positif dengan neraca pembayaran.

Sementara itu Studi yang dilakukan oleh Maipita (2012) tentang keterkaitan instrument kebijakan moneter dengan Balance of Payments di Indonesia menemukan bahwa ada kaitan antara instrument kebijakan moneter dengan neraca pembayaran di Indonesia. Terbukti bahwa operasi pasar terbuka (OPT) berkorelasi positif dan signifikan mempengaruhi neraca pembayaran, giro wajib minimum (GWM) mempengaruhi secara signifikan terhadap neraca pembayaran dengan memiliki korelasi negative, dan tingkat suku bunga domestik secara signifikan mempengaruhi neraca pembayaran dengan memiliki korelasi positive.

\section{Gambar 1}

Kondisi Neraca Pembayaran Indonesia, Neraca Transaksi Berjalan, dan Neraca Transaksi Modal dan Finansial Tahun 2002 - 2017 (Dalam Juta USD)

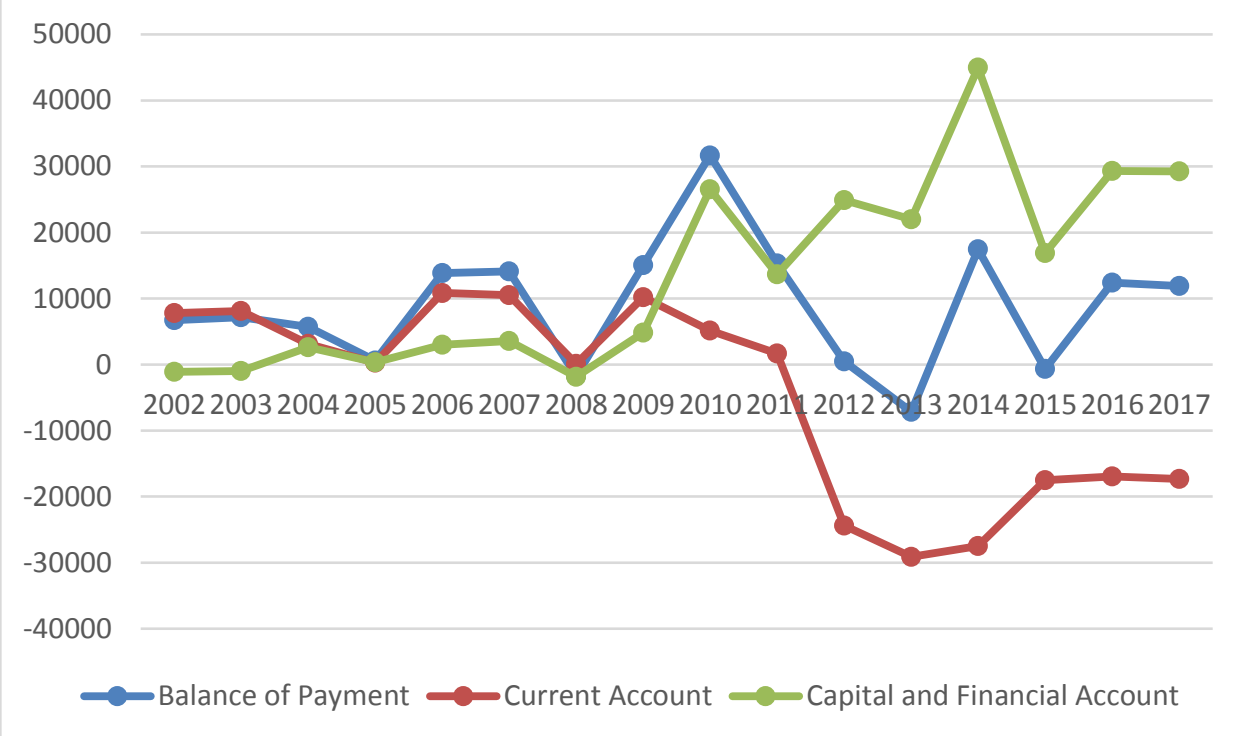

Sumber: Bank Indonesia, Statistik Ekonomi dan Keuangan Indonesia (SEKI)

Dari gambar 1 dapat dilihat bahwa pada tahun 2002 gap antara balance of payment Indonesia, neraca transaksi berjalan, dan neraca transaksi modal dan finansial tidak terlalu besar. Pada tahun 2010 terjadi perubahan gap dan terdapat perbedaan 
trend antara neraca pembayaran dengan neraca transaksi berjalan. Tahun 2012 juga terjadi perubahan gap dan trend antara neraca pembayaran dengan transaksi modal dan finansial.

Penilitian ini berfokus pada pengaruh variabel instrumen kebijakan moneter dan defisit anggaran terhadap neraca pembayaran Indonesia. Selain itu juga menganalisis interaksi dan keterkaitan variabel determinan neraca pembayaran Indonesia.

\section{TINJAUAN PUSTAKA}

Neraca pembayaran adalah transaksi yang dilakukan suatu negara dalam hubungan ekonominya dengan negara asing, dalam bentuk barang, jasa, dan aliran dana (Dumairy 1997). Neraca pembayaran didefinisikan sebagai pencatatan transaksi ekonmi dan financial secara sistematis pada periode tertentu antar penduduk domestic dan asing di seluruh dunia (Imoisi, Olatunji, and Ekpeyong 2013). Prosedur sistematis neraca pembayaran mencatat transaksi ekonomi yang dilakukan dengan metode double-entry book keeping. Total debit dan kredit diharuskan sama pada neraca pembayaran, namun bisa saja terjadi defisit maupun surplus pada beberapa bagian neraca pembayaran (Masdjojo 2010).

\section{Tabel 1}

\section{Anatomi Neraca Pembayaran}

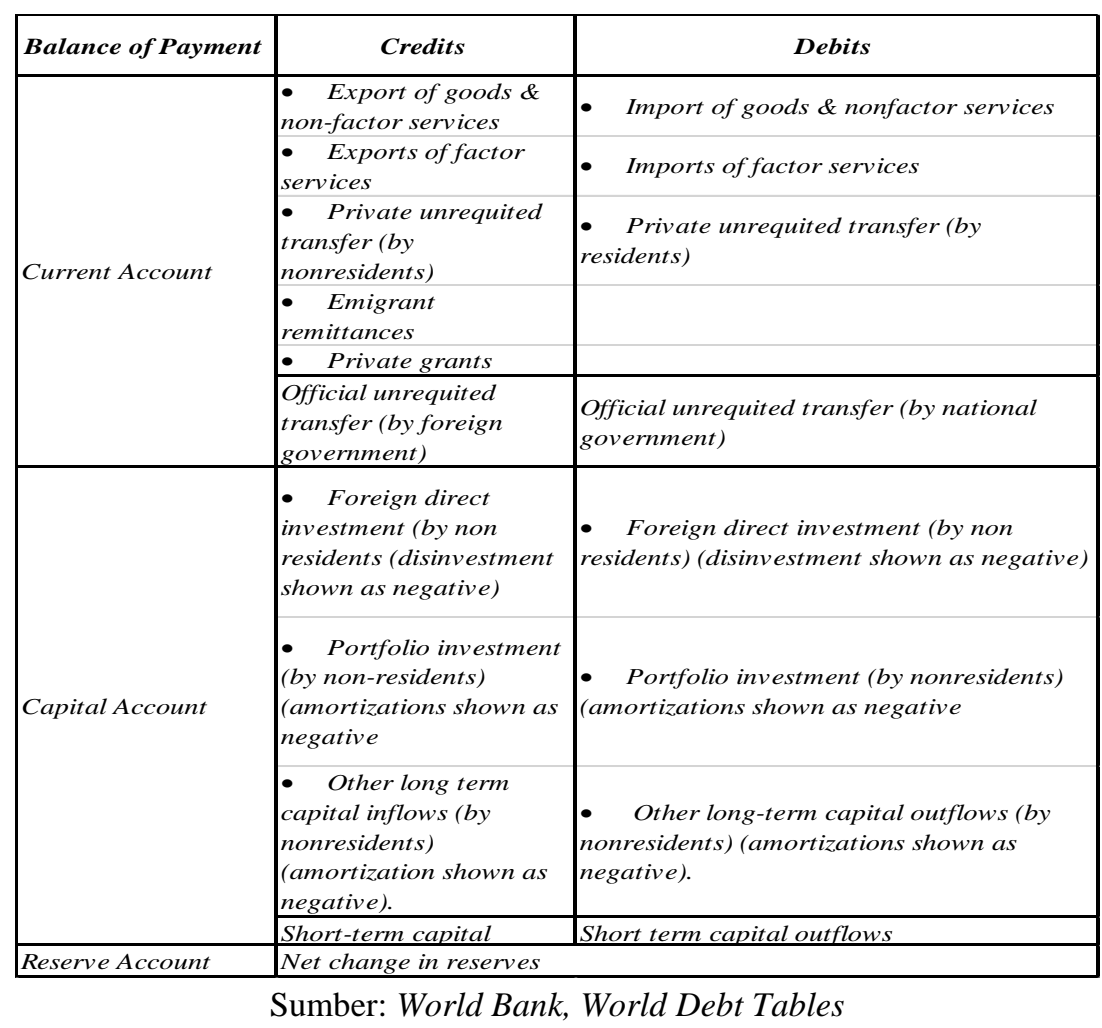


Dalam Neraca pembayaran terdapat current account dan financial account. Jika negara mengalami inflasi relative lebih tinggi dibandingkan negara lain maka current account akan diprediksikan menurun dikarenakan kenaikan impor dan penurunan ekspor (Shafi et al., (2015). Anatomi neraca pembayaran Indonesia umumnya dipakai oleh negara yang mempunyai sifat perekonomian yang terbuka tabel 2.1 merupakan contoh model yang dikembangakan oleh Bank Dunia.

Menurut Jamli (2001) ada dua pendekatan dalam teori neraca pembayaran yaitu pendekatan elastisitas dan pendekatan absorbsi, kedua pendekatan ini dikenal dengan pendekatan Keynesian. Selain itu ada juga pendekatan monetaris.

Pendekatan elastisitas pertama kali diperkenalkan oleh Robinson (1937), pendekatan tersebut menganalisis bahwa tingkat bunga dan nilai tukar akan memberikan pengaruh terhadap neraca pembayaran yang bergantung pada elastisitas permintaan dan penawaran nilai tukar dan barang luar negeri (Adamu and Itsede 2009). Selisih tingkat bunga domestic dan luar negeri menjadi salah satu insentif bagi investor menanamkan modalnya sehingga dapat menyebabkan perubahan pada nilai tukar. Perubahan nilai tukar mata uang (depresiasi atau apresiasi) diharapkan dapat memperbaiki neraca pembayaran. Ketika suatu komoditas ekspor bersifat elastis di negara lain, maka penurunan nilai tukar akan semakin efektif jika permintaan meningkat lebih besar dibandingkan penurunan nilai tukar (Celina 2015).

Pendekatan absorbsi pertamakali diperkenalkan oleh Alexander (1952). Pendekatan absorbsi menunjukuan bagaimana devaluasi dapat mengubah hubungan antara pengeluaran, absorbsi domestik dan pendapatan secara nominal dan nyata. Permulaan pendekatan absorbsi dimulai dari persamaan identitas pendapatan nasional (Adamu and Itsede 2009):

$\mathrm{Y}=\mathrm{C}+\mathrm{I}+\mathrm{G}+(\mathrm{X}-\mathrm{M})$

Dimana $\mathrm{Y}=$ pendapatan nasional; $\mathrm{C}=$ konsumsi barang dan jasa; $\mathrm{I}=$ total investasi oleh perusahaan maupun pemerintah; $\mathrm{G}=$ pengeluaran pemerintah; $\mathrm{X}=$ ekspor; $\mathrm{M}=$ Impor. Mengkombinasikan pengeluaran $\mathrm{C}+\mathrm{I}+\mathrm{G}$ menjadi satu dinamakan sebagai absorbsi domestik disimbolkan dengan (A) dan $\mathrm{X}-\mathrm{M}$ dikombinasikan menjadi neraca perdagangan, disimbolkan sebagai (B) sehingga:

$\mathrm{Y}=\mathrm{A}+\mathrm{B}$

$\mathrm{B}=\mathrm{Y}-\mathrm{A}$

Fungsi diatas menunjukan jika total absorbsi lebih besar dari pendapatan nasional (production) maka akan menghasilkan impor yang lebih besar daripada ekspor sehingga akan membuat neraca pembayaran defisit. Defisit tersebut dapat diperbaiki dengan peningkatan pendapatan dan pengurangan absorbsi. Kebijaksanaan tersebut dikenal sebagai expenditure switching policies dan expenditure reducing policies.

Menurut Marsha (1994) dalam penelitian Imoisi et al (2013) kebijakan expenditure reducing adalah perubahan kebijakan fiscal dan kebijakan moneter yang menyebabkan perubahan jumlah uang beredar dimana mempengaruhi tingkat suku 
bunga. Expenditure reducing merupakan pengurangan keseluruhan pengeluaran, termasuk dalam kegiatan pengurangan impor dan pengeluaran pemerintah. Tidak hanya menurunkan pengeluaran tetapi juga meningkatkan pendapatan pajak. Tujuan dari expenditure reducing adalah mengurangi pengeluaran domestic pada konsumsi dan meningkatkan investasi yang mana dapat meningkatkan ekspor barang maupun jasa. Sementara itu kebijakan expenditure switching lebih mengarah pada nilai tukar devaluasi dan revaluasi mata uang negara. Tujuan melakukan expenditure switching adalah untuk mengubah permintaan barang impor menjadi barang domestic, hal tersebut didukung dari tingkat elastisitas sebuah komoditas.

Pendekatan monetaris menurut Chacoliades (1990) pada penelitian Adamu dan Itsede (2009) ialah pendekatan yang menganggap neraca pembayaran merupakan fenomena moneter, dimana adanya hubungan antara neraca pembayaran suatu negara dan jumlah uang bereda. Menurut Nopirin (1990) ketidakseimbangan pasar uang merupakan cerminan neraca pembayaran yang tidak seimbang. Neraca pembayaran yang surplus merupakan indikasi dari kelebihan penawaran uang, jika sebaliknya maka terindikasi kekurangan penawaran uang.

Dasar utama pendekatan moneter adalah anggapan adanya stabilitas dalam permintaan akan uang serta pemerintah tidak melakukan tindakan sterilisasi. Tindakan sterilisasi yaitu tindakan pemerintah untuk mengurangi atau bahkan menghilangkan pengaruh neraca pembayaran terhadap jumlah uang beredar. Caranya apabila terdapat surplus pada neraca pembayaran maka untuk mencegah pengaruhnya terhadap jumlah uang beredar, pemerintah melakukan kebijakan pengurangan jumlah uang beredar dengan instrumen seperti jual surat berharga. Dengan adanya kebijakan tersebut maka pengaruh neraca pembayaran terhadap jumlah uang beredar hanya terjadi apabila memakai sistem kurs tetap, sedangkan didalam sistem kurs mengambang neraca pembayaran yang surplus/defisit berakibat kurs valuta asing turun/naik. Surplus/defisit dalam neraca pembayaran yang menyebabkan bertambah/berkurang jumlah uang beredar sampai permintaan/penawaran pada titik keseimbangan.maka dari itu neraca pembayaran yang tidak seimbang merupakan refleksi dari ketidakseimbangan pasar uang. Neraca pembayaran yang defisit merupakan refleksi dari adanya kurangnya permintaan jumlah uang beredar dan sebaliknya surplus sebagai refleksi kelebihan permintaan jumlah uang beredar.

Robert Mundell dan Marcus Fleming memperkenalkan model IS-LM untuk ekonomi yang terbuka, model tersebut dikenal sebagai model Mundell-Fleming. Model tersebut merupakan suatu mekanisme transmisi kebijakan moneter yang mengasumsikan negara terbuka kecil dengan mobilitas modal yang sempurna, sehingga dapat meminjam sebanyak yang dibutuhkan di pasar uang dunia. Mobilitas modal sempurna menyebabkan tingkat bunga domestik ditentukan oleh tingkat bunga dunia dan perekonomian berjalan sesuai kurs yang diadopsi dengan asumsi kurs mengambang (Mankiw 2000). 


\section{Gambar 2}

Kebijakan Moneter Ekspansif dengan Kurs Mengambang

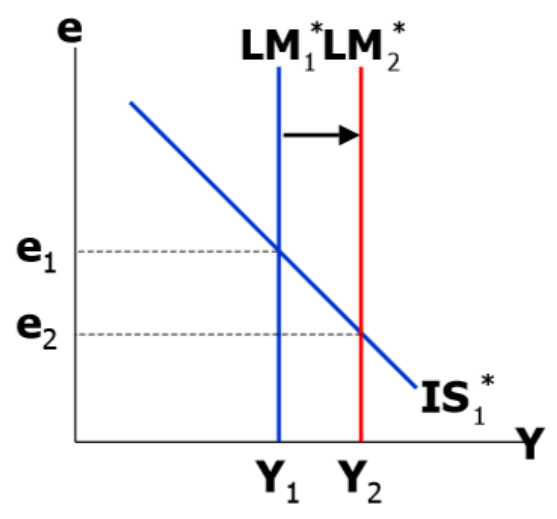

Sumber : Mankiw (2000)

Pada gambar 2 menunjukan kebijakan moneter ekspansif dengan menaikan jumlah uang beredar menyebabkan pergeseran kurva LM ke kanan sehingga akan terjadi depresiasi mata uang yang berdampak pada meningkatnya ekspor sehingga akan meningkatkan neraca perdagangan yang merupakan bagian dari neraca pembayaran (Mankiw 2000).

\section{Gambar 3}

\section{Kebijakan Fiskal Ekspansif dengan Kurs Mengambang}

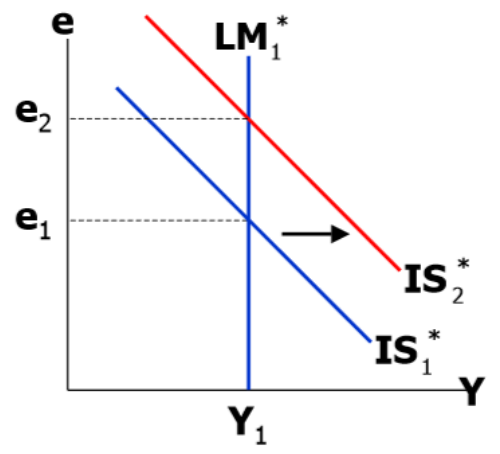

Sumber : Mankiw (2000)

Pada gambar 3 terlihat bahwa ketika terjadi kebijakan fiskal ekspansif maka akan menyebabkan IS bergeser ke kanan sehingga akan terjadi apresiasi mata uang, dengan terjadinya mata uang yang menguat maka akan menurunkan ekspor sehingga menurunkan neraca berjalan yang merupakan bagian dari neraca pembayaran. Menurut Leachman dan Francis (2002) dalam Nizar (2012) penguatan nilai tukar mata uang domestik akan memperburuk neraca transaksi berjalan melalui peningkatan impor dan penurunan ekspor. Sehingga dapat dikatakan ekspansi fiscal melalui 
peningkatan defisit anggaran mendorong peningkatan impor yang kemudian menyebabkan defisit neraca perdagangan dan akan berdampak pada ketidakseimbangan current account dikarenakan nilai tukar yang menguat (Nizar 2012).

Mundell (1995) dalam Blejer, Khan, \& Masson (1995) mengemukakan kebijakan moneter lebih efektif dibandingkan kebijakan fiscal untuk menjaga keseimbangan neraca pembayaran Indonesia. Hal tersebut diungkapkan dengan latar belakang kebijakan moneter dapat memperbaiki neraca transaksi berjalan dan neraca modal dan finansial.

Studi empiris yang dilakukan oleh Hermawan (2006) tentang kausalitas antara tingkat bunga dan neraca pembayaran di Indonesia. Studi empiris tersebut menyatakan bahwa pada lag satu kuartal terdapat hubungan kausalitas hanya satu arah dimana neraca pembayaran mempengaruhi pergerakan tingkat suku bunga.

Studi yang dilakukan oleh Maipita (2012) tentang keterkaitan instrument kebijakan moneter dengan Balance of Payments di Indonesia menemukan bahwa ada kaitan antara instrument kebijakan moneter dengan neraca pembayaran di Indonesia. Terbukti bahwa operasi pasar terbuka (OPT) berkorelasi positif dengan neraca pembayaran dengan pengaruh yang signfikan, giro wajib minimum (GWM) mempengaruhi secara signifikan terhadap neraca pembayaran dengan memiliki korelasi negative, dan tingkat suku bunga domestik secara signifikan mempengaruhi neraca pembayaran dengan memiliki korelasi positive.

Studi yang dilakukan oleh Imoisi et al. (2013) menemukan bahwa jumlah uang beredar, tingkat suku bunga, dan nilai tukar mempengaruhi neraca pembayaran Nigeria tahun 1980-2010. Hasil dari penelitian tersebut mengemukakan bahwa jumlah uang beredar memiliki korelasi positif dan mempengaruhi neraca pembayaran secara signifikan. Tingkat suku bunga memiliki korelasi negative dengan neraca pembayaran dan memiliki kontribusi yang signifikan. Hanya nilai tukar yang tidak memiliki pengaruh yang tidak signifikan dengan korelasi positif dengan neraca pembayaran.

Di dalam penelitian Celina (2015) meneliti tentang kebijakan moneter dan neraca pembayaran di Nigeria tahun 1981-2012. Hasil penelitiannya mengungkapkan bahwa jumlah uang beredar secara signifikan dan memiliki korelasi positif dengan neraca pembayaran. Sedangkan tingkat suku bunga tidak signifikan mempengaruhi neraca pembayaran dan memiliki korelasi negative terhadap neraca pembayaran.

Dalam penelitian Nizar (2012) tentang penurunan surplus neraca perdagangan barang (trade balance), defisit neraca jasa (service accounts), dan defisit neraca pendapatan neto (net income). Defisit neraca pendapatan telah menjadi penyumbang masalah terbesar bagi defisit transaksi berjalan dikarenakan pendapatan yang harus ditransfer ke luar negeri lebih besar dari pendapatan yang di dapat. Besaran bunga pinjaman ini dicatat di APBN dan sebagai salah satu kontribusi cukup besar dalam defisit anggaran. Maka dari itu ada keterkaitan antara defisit anggaran dengan neraca pembayaran dipengaruhi melalui neraca transaksi berjalan. Hal tersebut diperkuat dengan bukti empiris penelitian tersebut ditemukan bahwa defisit anggaran secara signifikan mempengaruhi dan memiliki hubungan positif dengan defisit transaksi berjalan dengan lag satu kuartal. 
Rafiq (2010) dalam penelitiannya tentang hubungan neraca berjalan dengan kebijakan fiscal dan nilai tukar riil. Penelitian tersebut menemukan bahwa terjadi hipotesis twin-deficit, hal ini dibuktikan bahwa defisit anggaran memiliki korelasi negative terhadap neraca berjalan.

Penelitian Bhat \& Sharma (2018) tentang pengujian kembali tentang hipotesis twin-deficit. Dalam penelitiannya dibuktikan secara empiris bahwa neraca berjalan dan defisit fiscal memiliki hubungan yang sama sehingga memvalidasi hipotesis twindeficit.

\section{METODE PENELITIAN}

\section{A. Definisi Operasional}

Dalam penelitian ini, menggunakan variabel instrumen kebijakan moneter yang terdiri dari

1. Neraca Pembayaran Indonesia (NPI)

Merupakan pencatatan transaksi ekonomi yang terjadi antara penduduk dengan penduduk internasional yang merupakan total dari neraca berjalan ditambah dengan neraca modal dan finansial, hasil dari penjumlahan tersebut dikatakan surplus neraca pembayaran ketika hasil akhir perhitungan positif, sebaliknya dikatakan defisit neraca pembayaran ketika hasil akhir perhitungan negatif. Data neraca pembayaran dinyatakan dalam satuan juta USD.

2. Operasi Pasar Terbuka (OPT)

Merupakan penerbitan dan pembelian surat berharga. Dikatakan penerbitan lebih banyak dari pada pembelian ketika hasil netto dari penjumlahan keduanya positif, sebaliknya dikatakan pembelian surat berharga lebih banyak dari penerbitan ketika hasil netto dari penjumlahan keduanya negatif. Data operasi pasar terbuka dinyatakan dalam satuan miliar rupiah.

3. Giro Wajib Minimum (GWM)

Merupakan cadangan minimum bank umum yang berbentuk dalam giro dan disimpan di Bank Indonesia baik rupiah maupun valuta asing. Data giro wajib minimum dinyatakan dalam satuan miliar rupiah.

4. Jumlah Uang Beredar (JUB)

Merupakan jumlah uang beredar dalam arti luas (M2). Dalam penelitian ini diasumsikan money supply dan money demand dalam keadaan seimbang. Data jumlah uang beredar dinyatakan dalam satuan miliar rupiah.

5. BI rate

Merupakan instrumen kebijakan moneter yang mengatur tingkat suku bunga yang telah ditetapkan oleh Bank Indonesia sebagai acuan arah perekonomian. Data BI rate dinyatakan dalam satuan persen.

6. Defisit Anggaran (DA)

Merupakan perhitungan anggaran pengeluaran dan penerimaan pajak. Dikatakan defisit anggaran apabila pengeluaran lebih besar daripada penerimaan dan hasil akhir perhitungan negatif, sebaliknya dikatakan surplus anggaran apabila penerimaan lebih kecil daripada pengeluaran dan hasil akhir perhitungan positif. Data defisit anggaran dinyatakan dalam dalam satuan miliar rupiah. 


\section{B. Jenis dan Sumber Data}

Data yang digunakan dalam penelitian ini adalah data sekunder. Data sekunder merupakan jenis data yang diperoleh peneliti dari instansi atau lembaga terkait. Penelitian ini menggunakan jenis data time series. Dalam penelitian ini menggunakan data time series kuartalan dalam periode 2002Q1 - 2017Q4.

Data diperoleh dari 2 institusi dalam negeri yaitu dari Bank Indonesia dalam Statistik Ekonomi dan Keuangan Indonesia (SEKI) sebagai pengambilan data instrumen kebijakan moneter dan neraca pembayaran Indonesia, sementara itu data defisit anggaran bersumber dari Kementerian Keuangan Indonesia dalam realisasi anggaran.

\section{Metode Analisis}

Metode analisis yang digunakan dalam penelitian ini adalah model Vector Autoregression (VAR) / Vector Error Correction Model (VECM). Menggunakan VAR apabila asumsi variabel stasioner pada tingkat level, apabila data tidak stasioner pada tingkat level maka dilakukan tahapan uji kointegrasi. Jika terdapat kointegrasi dalam persamaan analisis kuantitatif maka dapat menggunakan model Vector Error Correction Model (VECM).

Pada dasarnya VAR/VECM menganggap semua variabel dalam tersebut adalah endogen kemudian diestimasi secara bersama-sama dan simultan (Gujarati 2009). Variabel endogen adalah variabel yang besar kecilnya dipengaruhi oleh variabel lain, sebaliknya variabel eksogen adalah variabel yang besar kecilnya tidak dipengaruhi oleh variabel lain. Kebijakan bersifat tidak dipengaruhi oleh variabel lain, sehingga akan dalam penelitian ini variabel kebijakan diperlakukan sebagai variabel eksogen yaitu operasi pasar terbuka, giro wajib minimum, BI rate, defisit anggaran.

Sebelum melakukan estimasi menggunakan VAR/VECM perlu dilakukan pengujian analisis data time series dengan unit root test, penentuan lag optimum, uji kointegrasi, dan uji stabilitas. Apabila semua asumsi sudah diuji lalu maka dapat dilakukan estimasi menggunakan VAR/VECM, granger causality, impulse response function (IRF), variance decomposition (VD), dan uji asumsi klasik.

Alat analisis yang digunakan adalah Eviews 10. Persamaan dalam model penelitian ini dapat ditulis sebagai berikut:

1. $N P I_{t}=\beta_{1}+\sum_{i=1}^{\mathrm{k}} \beta_{2} N P I_{t-i}+\sum_{i=1}^{k} \beta_{3} J U B_{t-i}+\beta_{4} O P T+\beta_{5} G W M+$

$$
\beta_{6} \text { BIrate }+\beta_{7} D A+\varepsilon_{1 t}
$$

2. $J U B_{t}=\beta_{8}+\sum_{i=1}^{\mathrm{k}} \beta_{9} N P I_{t-i}+\sum_{i=1}^{\mathrm{k}} \beta_{10} J U B_{t-i}+\beta_{11} O P T+\beta_{12} G W M+$

$$
\beta_{13} \text { BIrate }+\beta_{14} D A+\varepsilon_{2 t}
$$




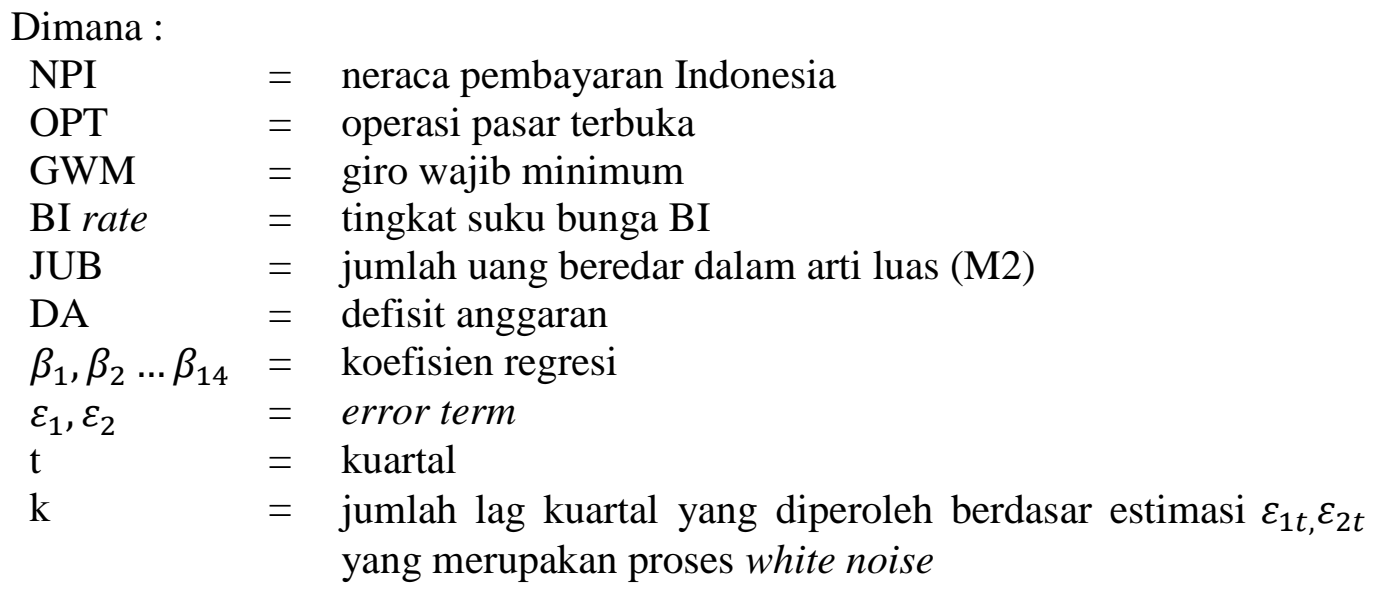

\section{HASIL DAN PEMBAHASAN}

Hasil analisis dari penelitian ini sudah lolos uji asumsi klasik yang terdiri dari uji normalitas, uji heterokedastisitas, dan uji autokorelasi. Berikut ini adalah hasil analisis dengan metode VAR/VECM.

\section{A. Uji Unit Root (Uji Stasioneritas)}

Langkah pertama yang dilakukan dalam analisis VAR/VECM yaitu dengan uji stasioneritas (uji unit root) dengan menggunakan Augmented Dickey-Fuller. Jika data stasioner pada tingkat level maka akan menggunakan VAR. Jika data stasioner pada first difference ataupun second difference maka akan dilanjutkan dengan uji kointegrasi untuk menentukan apakah data tersebut memiliki kointegrasi atau tidak memiliki kointegrasi.

Tabel 2

\section{Hasil Uji Unit Root}

\begin{tabular}{|c|c|c|c|c|}
\hline Variabel & Level & Keterangan & $\begin{array}{c}\text { First } \\
\text { Difference }\end{array}$ & Keterangan \\
\hline NPI & 0.0002 & Stasioner & 0.0000 & Stasioner \\
\hline BI rate & 0.0153 & Stasioner & 0.0068 & Stasioner \\
\hline $\begin{array}{c}\text { Defisit } \\
\text { Anggaran }\end{array}$ & 0.0089 & Stasioner & 0.0000 & Stasioner \\
\hline $\begin{array}{c}\text { Giro Wajib } \\
\text { Minimum }\end{array}$ & 0.4806 & $\begin{array}{c}\text { Tidak } \\
\text { Stasioner } \\
\text { Tidak } \\
\text { Stasioner }\end{array}$ & 0.0000 & Stasioner \\
\hline $\begin{array}{c}\text { Jumlah Uang } \\
\text { Beredar }\end{array}$ & 0.2973 & $\begin{array}{c}\text { Tidak } \\
\text { Stasioner }\end{array}$ & 0.0000 & Stasioner \\
\hline $\begin{array}{c}\text { Operasi Pasar } \\
\text { Terbuka }\end{array}$ & 0.1210 & Stasioner \\
\hline
\end{tabular}


Dari Tabel 2 menunjukan hasil uji unit root pada tingkat level terdapat lima variabel yang tidak stasioner yaitu BI rate, defisit anggaran, giro wajib minimum, jumlah uang beredar, dan operasi pasar terbuka. Uji unit root pada first difference menunjukan semua variabel memiliki nilai probabilita lebih kecil dari taraf nyata yaitu lima persen. Maka dapat disimpulkan data telah stasioner pada first difference.

\section{B. Uji Optimum Lag}

Lag optimal merupakan uji yang dilakukan dalam metode VAR/VECM, dikarenakan adanya asumsi suatu variabel mempengaruhi variabel lain tidak secara langsung melainkan membutuhkan jangka waktu atau biasa disebut dengan lag. Uji lag optimum bertujuan untuk mengetahui waktu yang dibutuhkan suatu variabel dalam merespon perubahan variabel lain. Uji lag yang digunakan dalam penelitian ini dengan melihat banyaknya lag optimum yang lolos dari beberapa kriteria uji lag. Uji lag dalam penelitian ini menggunakan 5 uji lag yaitu Likelihood Ratio test statistic (LR), Final Prediction Error (FPE), Akaike Information Criterion (AIC), Schwarz Information Criterion (SC), Hannan-Quinn Information Criterion (HQ). tanda bintang (*) mengindikasikan lag optimum dari kriteria salah satu uji lag. Lag optimum yang digunakan merupakan lag optimum dengan hasil uji kriteria terbanyak dalam uji lag.

\section{Tabel 3}

Hasil Penentuan Lag Optimum

\begin{tabular}{ccccccc}
\hline \hline Lag & LogL & LR & FPE & AIC & SC & HQ \\
\hline \hline 0 & -1444.791 & NA & $1.78 \mathrm{e}+18$ & 47.69805 & 48.04410 & 47.83367 \\
1 & -1337.721 & 189.5654 & $6.07 \mathrm{e}+16$ & 44.31873 & 44.80319 & 44.50860 \\
2 & -1323.956 & $23.46897^{*}$ & $4.42 \mathrm{e}+16^{*}$ & $43.99855^{*}$ & $44.62143^{*}$ & $44.24266^{*}$ \\
3 & -1322.970 & 1.616074 & $4.90 \mathrm{e}+16$ & 44.09738 & 44.85868 & 44.39574 \\
$=$
\end{tabular}$==$

Lag optimum berdasarkan dari informasi tabel 3 memperlihatkan bahwa lag terbanyak ada pada lag ke dua. Terdapat empat kriteria yang mengindikasikan lag optimum ada pada lag ke dua yaitu kriteria LR, FPE, AIC, dan HQ.

\section{Uji Kointegrasi}

Uji kointegrasi dilakukan untuk melihat apakah antar variabel penelitian memiliki hubungan jangka panjang atau tidak. Jika terdapat hubungan jangka panjang maka akan memakai metode VECM. Sebaliknya jika tidak ada kointegrasi maka akan memakai metode unrestricted VAR.

Selanjutnya melakukan uji kointegrasi dengan metode Johansen dengan membandingkan nilai $t$-statistic dengan nilai critical value (0.05) atau membandingkan maximum eigenvalue dengan critical value (0.05). Jika trace-statistic atau maximum eigenvalue lebih besar daripada nilai critical value maka dapat disimpulkan data mengalami keseimbangan pada jangka panjang. 


\section{Tabel 4}

Hasil Uji Kointegrasi dengan Metode Johansen Cointegration Test

\begin{tabular}{|c|c|c|c|c|}
\hline $\begin{array}{c}\text { Hypothesized } \\
\text { No. of CE(s) }\end{array}$ & Trace Statistic & Critical Value & $\begin{array}{c}\text { Maximum } \\
\text { eigenvalue }\end{array}$ & Critical Value \\
\hline None* & 21.99319 & 20.26184 & 19.67609 & 15.89210 \\
\hline At most 1 & 2.317093 & 9.164546 & 2.317093 & 9.164546 \\
\hline
\end{tabular}

Sumber: Hasil pengolahan uji kointegrasi

Hasil pada tabel 4 menunjukan bahwa nilai trace statistic 21,99319 lebih besar daripada critical value 20,26184. Pada Maximum eigenvalue 19,67609 lebih besar dari pada critical value 15,89210. Hasil tersebut mengindikasikan setidaknya satu kointegrasi diantara variabel, sehingga variabel-variabel dalam model memiliki hubungan keseimbangan dalam jangka panjang. Dikarenakan adanya kointegrasi maka penelitian tersebut menggunakan metode VECM.

\section{Granger Causality}

Uji granger causality merupakan uji untuk menganalisis hubungan kausalitas dan melihat arah hubungan antar variabel dalam penelitian. Dalam penelitian ini uji kausalitas menggunakan metode Pairwise Granger Causality.

\section{Tabel 5}

\section{Pairwise Granger Causality}

Lags: 2

\begin{tabular}{lccc}
\hline \hline Null Hypothesis: & Obs & F-Statistic & Prob. \\
\hline \hline BI_RATE does not Granger Cause NPI & 62 & 0.02163 & 0.9786 \\
NPI does not Granger Cause BI_RATE & & 0.34191 & 0.7119 \\
\hline \hline DA does not Granger Cause NPI & 62 & 0.25636 & 0.7747 \\
NPI does not Granger Cause DA & & 1.01158 & 0.3701 \\
\hline \hline GWM does not Granger Cause NPI & 62 & 0.23067 & 0.7947 \\
NPI does not Granger Cause GWM & & 2.05069 & 0.1380 \\
\hline \hline JUB does not Granger Cause NPI & 62 & 0.10588 & 0.8997 \\
NPI does not Granger Cause JUB & & 2.55045 & 0.0869 \\
\hline \hline OPT does not Granger Cause NPI & 62 & 0.42827 & 0.6537 \\
NPI does not Granger Cause OPT & & 3.79151 & 0.0284 \\
\hline \hline DA does not Granger Cause BI_RATE & 62 & 2.87293 & 0.0648 \\
BI_RATE does not Granger Cause DA & & 1.30246 & 0.2798 \\
\hline \hline GWM does not Granger Cause BI_RATE & 62 & $\begin{array}{l}1.60703 \\
1.27564\end{array}$ & $\begin{array}{l}0.2094 \\
0.2871\end{array}$ \\
BI_RATE does not Granger Cause GWM & & &
\end{tabular}




\begin{tabular}{|c|c|c|c|}
\hline $\begin{array}{l}\text { JUB does not Granger Cause BI_RATE } \\
\text { BI_RATE does not Granger Cause JUB }\end{array}$ & 62 & $\begin{array}{l}3.38635 \\
1.27691\end{array}$ & $\begin{array}{l}0.0408 \\
0.2868\end{array}$ \\
\hline $\begin{array}{l}\text { OPT does not Granger Cause BI_RATE } \\
\text { BI_RATE does not Granger Cause OPT }\end{array}$ & 62 & $\begin{array}{l}1.15412 \\
0.03168\end{array}$ & $\begin{array}{l}0.3226 \\
0.9688\end{array}$ \\
\hline $\begin{array}{l}\text { GWM does not Granger Cause DA } \\
\text { DA does not Granger Cause GWM }\end{array}$ & 62 & $\begin{array}{l}3.58862 \\
2.94900\end{array}$ & $\begin{array}{l}0.0340 \\
0.0604\end{array}$ \\
\hline $\begin{array}{l}\text { JUB does not Granger Cause DA } \\
\text { DA does not Granger Cause JUB }\end{array}$ & 62 & $\begin{array}{l}7.13822 \\
13.0595\end{array}$ & $\begin{array}{l}0.0017 \\
2 . E-05\end{array}$ \\
\hline $\begin{array}{l}\text { OPT does not Granger Cause DA } \\
\text { DA does not Granger Cause OPT }\end{array}$ & 62 & $\begin{array}{l}1.41724 \\
0.18857\end{array}$ & $\begin{array}{l}0.2508 \\
0.8287\end{array}$ \\
\hline $\begin{array}{l}\text { JUB does not Granger Cause GWM } \\
\text { GWM does not Granger Cause JUB }\end{array}$ & 62 & $\begin{array}{l}1.57883 \\
1.18502\end{array}$ & $\begin{array}{l}0.2151 \\
0.3132\end{array}$ \\
\hline $\begin{array}{l}\text { OPT does not Granger Cause GWM } \\
\text { GWM does not Granger Cause OPT }\end{array}$ & 62 & $\begin{array}{l}1.83482 \\
0.72101\end{array}$ & $\begin{array}{l}0.1689 \\
0.4906\end{array}$ \\
\hline $\begin{array}{l}\text { OPT does not Granger Cause JUB } \\
\text { JUB does not Granger Cause OPT }\end{array}$ & 62 & $\begin{array}{l}1.93152 \\
1.15739\end{array}$ & $\begin{array}{l}0.1543 \\
0.3216\end{array}$ \\
\hline
\end{tabular}

Hasil VEC granger causality tabel 5 menunjukan hasil dimana terdapat hubungan kausalitas satu arah yakni variabel operasi pasar terbuka mempengaruhi neraca pembayaran Indonesia, terdapat juga hubungan kausalitas satu arah yaitu variabel BI rate mempengaruhi jumlah uang beredar, terdapat hubungan satu arah yaitu variabel defisit anggaran mempengaruhi giro wajib minimum, terdapat hubungan dua arah antara variabel defisit anggaran dan jumlah uang beredar.

\section{E. Analisis VECM}

Model VECM menggunakan nilai t-table sebagai penentu untuk menentukan hasil uji hipotesis terhadap koefisiennya. Jika nilai t-statistik lebih besar dari tabel-t maka terdapat pengaruh yang signifikan. Sebaliknya jika t-statistik memiliki nilai yang lebih kecil dari tabel-t maka dapat disimpulkan terdapat pengaruh yang tidak signifikan. Nilai kritis tabel-t pada signfikansi 1 persen, 5 persen, dan 10 persen masing-masing adalah 2,659, 2,000, dan 1,670. Dalam penelitian ini dikatakan signifikan dengan tingkat keyakinan 95\%. Model VECM lag yang digunakan dalam penelitian ini sebesar 2 hal tersebut sesuai dengan hasil uji lag optimum. Berikut hasil estimasi model VECM. 


\section{Tabel 6}

\section{Hasil Estimasi VECM}

Standard errors in ( ) \& t-statistics in [ ]

\begin{tabular}{|c|c|c|}
\hline Error Correction: & $\mathrm{D}(\mathrm{NPI})$ & $\mathrm{D}(\mathrm{JUB})$ \\
\hline CointEq1 & $\begin{array}{r}-0.884307 \\
(0.19998) \\
{[-4.42201]}\end{array}$ & $\begin{array}{r}-0.401318 \\
(2.98494) \\
{[-0.13445]}\end{array}$ \\
\hline $\mathrm{D}(\mathrm{NPI}(-1))$ & $\begin{array}{c}0.019884 \\
(0.16603) \\
{[0.11976]}\end{array}$ & $\begin{array}{r}-3.325072 \\
(2.47819) \\
{[-1.34174]}\end{array}$ \\
\hline $\mathrm{D}(\mathrm{NPI}(-2))$ & $\begin{array}{c}0.125592 \\
(0.13431) \\
{[0.93506]}\end{array}$ & $\begin{array}{r}-1.232241 \\
(2.00482) \\
{[-0.61464]}\end{array}$ \\
\hline $\mathrm{D}(\mathrm{JUB}(-1))$ & $\begin{array}{r}-0.003148 \\
(0.00944) \\
{[-0.33357]}\end{array}$ & $\begin{array}{r}-0.630546 \\
(0.14088) \\
{[-4.47582]}\end{array}$ \\
\hline $\mathrm{D}(\mathrm{JUB}(-2))$ & $\begin{array}{r}-0.005399 \\
(0.00896) \\
{[-0.60273]}\end{array}$ & $\begin{array}{r}-0.095845 \\
(0.13370) \\
{[-0.71685]}\end{array}$ \\
\hline BI_RATE & $\begin{array}{r}375.1023 \\
(139.684) \\
{[2.68537]}\end{array}$ & $\begin{array}{r}-92.73534 \\
(2084.97) \\
{[-0.04448]}\end{array}$ \\
\hline DA & $\begin{array}{r}-0.006423 \\
(0.00852) \\
{[-0.75361]}\end{array}$ & $\begin{array}{r}0.209150 \\
(0.12722) \\
{[1.64405]}\end{array}$ \\
\hline GWM & $\begin{array}{r}-0.021073 \\
(0.00925) \\
{[-2.27878]}\end{array}$ & $\begin{array}{r}0.433913 \\
(0.13803) \\
{[3.14366]}\end{array}$ \\
\hline OPT & $\begin{array}{r}0.020875 \\
(0.00743) \\
{[2.81123]}\end{array}$ & $\begin{array}{r}0.218400 \\
(0.11084) \\
{[1.97050]}\end{array}$ \\
\hline $\begin{array}{l}\text { uared } \\
\text { tistic }\end{array}$ & $\begin{array}{l}0.431298 \\
4.929540\end{array}$ & $\begin{array}{l}0.552726 \\
8.032473\end{array}$ \\
\hline
\end{tabular}

Hasil VECM tabel 6 dimana variabel eksogen yaitu BI rate, defisit anggaran, giro wajib minimum, dan operasi pasar terbuka dapat diinterpretasikan bagaimana pengaruh dengan variabel endogen neraca pembayaran Indonesia dan jumlah uang beredar. 
Variabel NPI sebagai salah satu variabel endogen dipengaruhi oleh variabel eksogen BI rate memiliki hubungan positif dan signifikan mempengaruhi neraca pembayaran Indonesia dengan koefisien 305,1023 yang dapat diartikan ketika terjadi peningkatan BI rate sebesar satu persen maka akan meningkatkan neraca pembayaran Indonesia sebesar 375 juta USD. Defisit anggaran memiliki hubungan negatif dan tidak signifikan mempengaruhi neraca pembayaran Indonesia. Giro wajib minimum memiliki hubungan negatif dan signifikan mempengaruhi neraca pembayaran Indonesia dengan koefisien -0,021073 yang dapat diartikan ketika terjadi kenaikan giro wajib minimum sebesar satu miliar rupiah maka akan menurunkan neraca pembayaran Indonesia sebesar -0,021073 juta USD. Operasi pasar terbuka memiliki hubungan positif dan siginifikan mempengaruhi neraca pembayaran Indonesia dengan koefisien 0,020875 yang dapat diartikan ketika terjadi kenaikan netto penjualan dan pembelian surat berharga (OPT) sebesar satu miliar maka akan meningkatkan neraca pembayan Indonesia sebesar 0,020875 juta USD.

Variabel JUB sebagai salah satu variabel endogen dipengaruhi oleh variabel eksogen. BI rate memiliki hubungan negatif dan tidak signifikan mempengaruhi jumlah uang beredar. Defisit anggaran memiliki hubungan positif dan tidak signifikan mempengaruhi jumlah uang beredar. Giro wajib minimum memiliki hubungan positif dan signifikan mempengaruhi jumlah uang beredar dengan koefisien 0,433913 yang dapat diartikan ketika terjadi kenaikan GWM sebesar satu miliar maka akan meningkatkan jumlah uang beredar sebesar 0,433913 miliar. Operasi pasar terbuka memiliki hubungan positif dan tidak signifikan mempengaruhi jumlah uang beredar.

Pada model VECM penilitian ini juga memiliki F-statistik pada variabel endogen NPI lebih besar dari nilai F-tabel dengan taraf nyata 5 persen $(4,92>2,37)$ yang dapat diartikan nilainya signifikan. Artinya semua variabel independen secara simultan mempengaruhi neraca pembayaran Indonesia. Selain itu juga memiliki F-statistik pada variabel endogen JUB lebih besar dari nilai F-tabel dengan taraf nyata 5 persen $(8,03>2,37)$ yang dapat ddiartikan nilainya signifikan. Artinya semua variabel independen secara simultan mempengaruhi jumlah uang beredar.

Nilai koefisien determinasi $R$-squared pada variabel endogen NPI sebesar 0,43 hal ini berarti seluruh variabel independen mampu menjelaskan variabel dependen sebesar 43 persen sementara sisanya 57 persennya dijelaskan oleh variabel lain diluar penelitian. Selain itu $R$-squared pada variabel endogen JUB sebesar 0,55 hal tersebut memiliki arti bahwa seluruh variabel independen mampu menjelaskan variabel dependen sebesar 55 persen sementara sisanya 45 persen dijelaskan oleh variabel lain diluar penelitian.

Hasil estimasi VECM dalam penelitian ini menemukan menemukan bahwa BI rate memiliki hubungan positif dan signifikan mempengaruhi neraca pembayaran Indonesia.. Hasil yang tidak sesuai hipotesis diindikasikan bahwa kenaikan BI rate dapat meningkatkan capital inflow sehingga meningkatkan mempengaruhi neraca pembayaran Indonesia melalui mobilitas aliran modal. Hasil yang menunjukan korelasi positif tersebut ditemukan juga dalam penelitian Maipita (2012) yang menunjukan hasil tingkat suku bunga domestik memiliki pengaruh yang signifikan dengan hubungan positif terhadap neraca pembayaran Indonesia. 
Hasil estimasi VECM dalam penelitian ini menemukan giro wajib minimum memiliki hubungan negatif dan signifikan mempengaruhi neraca pembayaran Indonesia, hubungan tersebut sesuai dengan teori dimana seharusnya ketika terjadi kenaikan GWM maka akan menurunkan JUB dan akan mencerminkan defisit neraca pembayaran Indonesia. Hasil penelitian tersebut ditemukan juga dalam penelitian Maipita (2012) dimana giro wajib minimum memiliki hubungan negatif dan signifikan mempengaruhi neraca pembayaran Indonesia.

Hasil estimasi VECM dalam penelitian ini menemukan operasi pasar terbuka memiliki hubungan positif dan signifikan mempengaruhi neraca pembayaran Indonesia, hal tersebut tidak sesuai dengan hipotesis, hal ini dimungkinkan karena pengaruh OPT terhadap NPI yang terjadi melalui mekanisme transmisi jalur suku bunga dimana ketika terjadi peningkatan OPT maka akan menurunkan JUB sehingga tingkat suku bunga meningkat dan memperburuk investasi sehingga ketika saving lebih besar dari investasi atau dapat dirumuskan sebagai berikut:

$\mathrm{Y}=\mathrm{C}+\mathrm{I}+\mathrm{G}(\mathrm{X}-\mathrm{M})$

$\mathrm{Y}-\mathrm{C}-\mathrm{G}=\mathrm{I}+\mathrm{NX}$

$\mathrm{Y}-\mathrm{C}-\mathrm{G}$ merupakan saving sehingga

$\mathrm{S}-\mathrm{I}=\mathrm{NX}$

maka ketika saving lebih besar maka net ekspor akan meningkat juga untuk dapat di titik persamaanya. Sehingga akan memperburuk neraca transaksi berjalan dan berimplikasi pada penurunan neraca pembayaran Indonesia. Hasil penelitian tersebut ditemukan juga dalam penelitian Maipita (2012) dimana operasi pasar terbuka memiliki hubungan positif dan signifikan mempengaruhi neraca pembayaran Indonesia.

Hasil estimasi VECM dalam penelitian ini menemukan giro wajib minimum memiliki hubungan positif dan signifikan mempengaruhi jumlah uang beredar, hasil tersebut tidak sesuai dengan hipotesis, hal ini mengindikasikan bahwa sumber pendanaan bank umum tidak lagi dari simpanan nasabah atau dikenal dengan loan to deposit ratio melainkan pendanaan sudah dari berbagai sumber atau dikenal dengan loan to funding ratio.

\section{F. Uji Stabilitas}

Uji stabilitas VECM dilakukan untuk mengetahui model yang digunakan stabil atau tidak. Berikut hasil uji stabilitas VECM. 


\section{Tabel 7}

Hasil Uji Stabilitas Tabel VECM

Lag specification: 12

\begin{tabular}{cc}
\hline \hline Root & Modulus \\
\hline \hline 1.000000 & 1.000000 \\
$0.359040-0.372912 \mathrm{i}$ & 0.517661 \\
$0.359040+0.372912 \mathrm{i}$ & 0.517661 \\
$-0.432703-0.117691 \mathrm{i}$ & 0.448423 \\
$-0.432703+0.117691 \mathrm{i}$ & 0.448423 \\
-0.346854 & 0.346854 \\
\hline \hline
\end{tabular}

Model VECM dikatakan stabil jika invers akar pada tabel 7 karakteristiknya memiliki modulus tidak lebih dari satu, dapat disimpulkan bahwa model VECM dalam penelitian ini sudah stabil.

\section{G. Impulse Response Function (IRF)}

\section{Gambar 4}

Respon NPI Terhadap Shock NPI Analisis Impulse Response Function

Response to Cholesky One S.D. (d.f. adjusted) Innovations

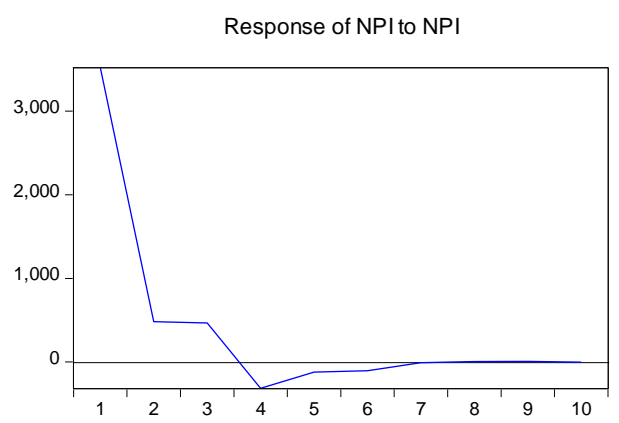

\section{Gambar 5}

Respon NPI Terhadap Shock JUB Analisis Impulse Response Function

Response to Cholesky One S.D. (d.f. adjusted) Innovations

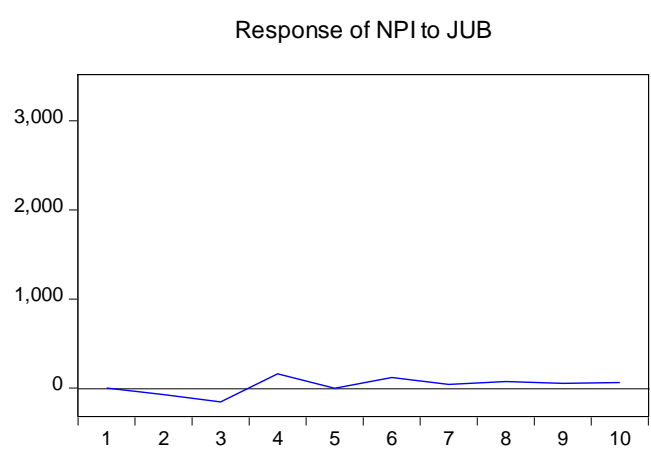


Dari gambar 4 terlihat bahwa jika terjadi shock positif sebesar 1 S.D. pada kelompok NPI maka akan di respon positif oleh NPI itu sendiri pada periode pertama, kemudian di respon negatif pada periode ke empat hingga ke tujuh dan mulai stabil pada periode ke 8 hingga 10 terlihat bahwa kembalinya ke titik origin seperti yang tergambarkan pada gambar 4 .

Sementara itu dari gambar 5 terlihat bahwa ketika terjadi shock positif sebesar 1 S.D pada kelompok JUB maka akan direspon negatif oleh NPI pada periode ke dua dan tiga, respon positif terjadi pada periode ke empat akan tetapi kembali negatif pada periode ke lima, dan positif pada periode ke enam hingga ke sepuluh. Terlihat dari gambar bahwa akibat dari shock tersebut maka terbentuk keseimbangan baru pada periode ke tujuh dimanaa menunjukan kondisi yang stabil dari gambar 5 .

\section{Gambar 6 \\ Respon JUB Terhadap JUB Analisis Impulse Response Function}

Response to Cholesky One S.D. (d.f. adjusted) Innovations

Response of JUB to NPI

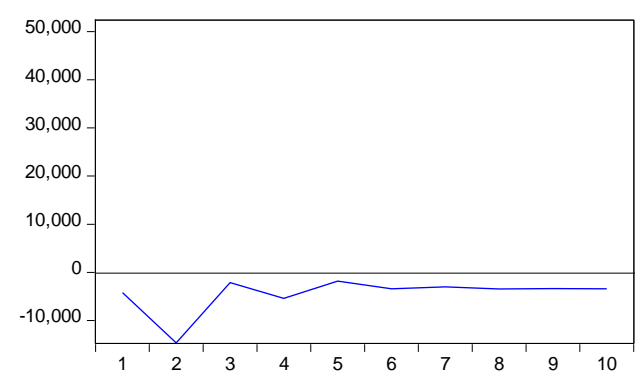

Gambar 7

Respon JUB Terhadap JUB Analisis Impulse Response Function

Response to Cholesky One S.D. (d.f. adjusted) Innovations

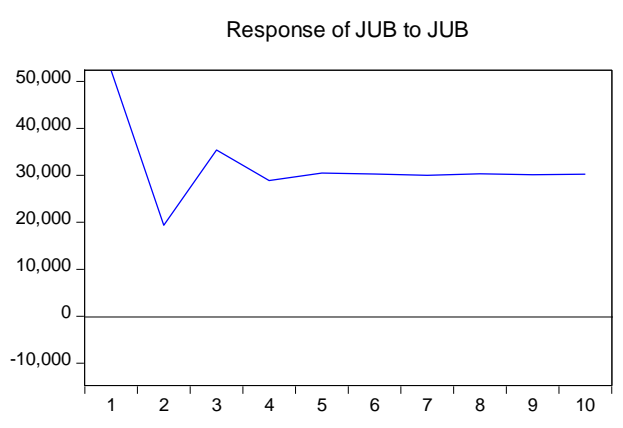

Dari Gambar 6 terlihat bahwa jika terjadi shock positif sebesar 1 S.D. pada kelompok NPI maka akan di respon negatif oleh JUB pada periode pertama, kemudian semakin menurun pada periode ke- 2 dan kembali meningkat hingga pada periode ke5 dan membuat keseimbangan baru pada periode ke- 8 .

Sementara itu dari gambar 7 terlihat bahwa ketika terjadi shock positif sebesar 1 S.D pada kelompok JUB maka akan direspon positif oleh JUB itu sendiri pada 
periode pertama, kemudian menurun pada periode ke-2 dan kembali meningkat pada periode ke-3. Respon tersebut stabil pada periode ke-5 sehingga dapat dikatakan membuat keseimbangan baru.

\section{H. Variance Decomposition (VD)}

\section{Tabel 8}

\section{Hasil Variance Decomposition Neraca Pembayaran Indonesia}

\begin{tabular}{|c|c|c|c|}
\hline \multirow[b]{2}{*}{ Period } & \multicolumn{3}{|c|}{ Variance Decomposition of NPI: } \\
\hline & S.E. & NPI & JUB \\
\hline 1 & 3513.728 & 100.0000 & 0.000000 \\
\hline 2 & 3547.434 & 99.95704 & 0.042962 \\
\hline 3 & 3581.372 & 99.77089 & 0.229108 \\
\hline 4 & 3598.654 & 99.57506 & 0.424942 \\
\hline 5 & 3600.670 & 99.57552 & 0.424477 \\
\hline 6 & 3604.174 & 99.46653 & 0.533474 \\
\hline 7 & 3604.414 & 99.45379 & 0.546207 \\
\hline 8 & 3605.146 & 99.41363 & 0.586372 \\
\hline 9 & 3605.531 & 99.39267 & 0.607335 \\
\hline 10 & 3606.049 & 99.36416 & 0.635845 \\
\hline
\end{tabular}

Pada tabel 8 dapat dilihat data pada periode pertama menunjukan shock yang dialami NPI disebabkan oleh NPI itu sendiri, dapat dilihat dari besarannya sebesar 100 persen sementara variabel lain belum berkontribusi pada shock NPI. Pada periode kedua shock NPI terbesar dikontribusi oleh NPI itu sendiri sebesar 99,95 persen. Pada periode kedua Selain NPI itu sendiri JUB berkontribusi sebesar 0,04 persen. Pada periode ke-10 shock NPI terbesar masih dikontribusi NPI itu sendiri sebesar 99,36 persen dapat terlihat bahwa kontribusinya menurun sejalan dengan bertambahnya periode, selanjutnya kontribusi oleh JUB sebesar 0,63 persen.

Tabel 9

Hasil Variance Decomposition Jumlah Uang Beredar

\begin{tabular}{cccc}
\hline \hline & \multicolumn{2}{c}{ Variance Decomposition of JUB: } & NPI \\
Period & S.E. & JUB \\
\hline \hline 1 & 52446.99 & 0.640402 & 99.35960 \\
2 & 57791.75 & 6.951247 & 93.04875 \\
3 & 67801.73 & 5.147176 & 94.85282 \\
4 & 73898.04 & 4.870192 & 95.12981 \\
5 & 79951.46 & 4.211175 & 95.78883 \\
6 & 85556.14 & 3.835102 & 96.16490 \\
7 & 90717.19 & 3.519481 & 96.48052 \\
8 & 95709.15 & 3.290504 & 96.70950 \\
9 & 100397.4 & 3.102214 & 96.89779 \\
10 & 104910.0 & 2.945290 & 97.05471 \\
\hline \hline
\end{tabular}


Pada Tabel 9 dapat dilihat shock JUB pada periode pertama dikontribusi oleh JUB itu sendiri sebesar 99,35 persen, sementara itu kontribusi NPI sebesar 0,64 persen. Pada periode ke-2 Shock pada JUB dikontribusi oleh JUB itu sendiri menurun yaitu sebesar 93,04 persen, lalu diikuti oleh kontribusi NPI yaitu sebesar 6,95 persen. Pada periode ke-10 kontribusi JUB pada shock JUB sebesar 97,05 persen dimana terjadi peningkatan kontribusi dari periode ke dua, kontribusi NPI sebesar 2,94 persen dimana terjadi penurunan kontribusi dari periode ke dua.

\section{KESIMPULAN}

Berdasarkan hasil penelitian mengenai analisis keterkaitan instrumen kebijakan moneter, defisit anggaran dan neraca pembayaran Indonesia pada tahun penelitian 2002 kuartal I hingga 2017 kuartal IV menemukan bahwa terdapat hubungan kausalitas satu arah yaitu operasi pasar terbuka dengan neraca pembayaran Indonesia, dimana operasi pasar terbuka merupakan salah satu instrumen kebijakan moneter.

BI rate, giro wajib minimum, dan operasi pasar terbuka mempangaruhi neraca pembayaran Indonesia secara signifikan. Oleh karena itu penelitian ini menunjukan bahwa instrumen kebijakan moneter (BI rate, giro wajib minimum, dan operasi pasar terbuka) merupakan instrumen yang dapat digunakan untuk menjaga stabilitas neraca pembayaran Indonesia. Hasil penelitian tersebut merepresentasikan bahwa neraca pembayaran Indonesia merupakan fenomena moneter.

\section{DAFTAR PUSTAKA}

Adamu, Patricia A., and Osi C. Itsede. 2009. "BALANCE OF PAYMENTS ADJUSTMENT: THE WEST AFRICAN MONETARY ZONE EXPERIENCE.” Journal of Monetary and Economic Integration 10 (2): 100116.

Bhat, Javed Ahmad, and Naresh Kumar Sharma. 2018. "The Twin-Deficit Hypothesis: Revisiting Indian Economy in a Nonlinear Framework." Journal of Financial Economic Policy 10 (3): 386-405. https://doi.org/10.1108/JFEP-092017-0082.

Blejer, Mario I., Mohsin S. Khan, and Paul R. Masson. 2007. "Early Contributions of 'Staff Papers' to International Economics." Staff Papers - International Monetary Fund 42 (4): 707. https://doi.org/10.2307/3867596.

Celina, Udude. 2015. "Monetary Policy and Balance of Payment in Nigeria (19812012)." Journal of Policy and Development Studies 9 (2): 14-26.

Departemen Statistik, Bank Indonesia. 2014. "Neraca Pembayaran Indonesia." Dumairy. 1997. Perekonomian Indonesia. Jakarta: Erlangga.

Gujarati, Damodar. 2009. Basic Econometrics. Third Edit. New york: McGraw-Hill. Hermawan, Wawan. 2006. "Pengujian Kausalitas Antara Tingkat Bunga Dan Neraca Pembayaran Di Indonesia Tahun 1999.1-2001.2.” BINA EKONOMI 10 (2): 1128.

Imoisi, Anthony Ilegbinosa, Lekan Moses Olatunji, and Bosco Itoro Ekpeyong. 
2013. "Monetary Policy and Its Implications for Balance of Payments Stability in Nigeria: 1980-2010." International Journal of Economics and Finance 5 (3): 196-204. https://doi.org/10.5539/ijef.v5n3p196.

Jamli, Ahmad. 2001. Dasar-Dasar Keuangan Internasional. Yogyakarta: BPFE. Maipita, Indra. 2012. "Keterkaitan Instrumen Kebijakan Moneter Dengan Neraca Pembayaran Di Indonesia." QE Journal 3 (1): 287-301.

Mankiw. 2006. Makro Ekonomi. Jakarta: Erlangga.

Mankiw, N. Gregory. 2000. Teori Makro Ekonomi. Jakarta: Erlangga.

Masdjojo, Gregorius Nasiansenus. 2010. "Kajian Pendekatan Keynesian Dan

Monetaris Terhadap Dinamika Cadangan Devisa Melalui Penelusuran Neraca

Pembayaran Internasional : Studi Empiris Di Indonesia Periode 1983-2008."

Universitas Diponegoro, 1-398.

Nizar, Muhammad Afdi. 2012. "PENGARUH DEFISIT ANGGARAN TERHADAP DEFISIT TRANSAKSI BERJALAN DI INDONESIA.” Pusat Kebijakan

Ekonomi Makro, Badan Kebijakan Fiskal, Kementerian Keuangan-RI.

Nopirin. 1990. Ekonomi Internasional. Vol. 2. Yogyakarta: BPFE.

Nwanosike., Uzoechina. B, Ebenyi. GO, and Ishiwu. 2017. "Analysis of Balance of Payments Trend in Nigeria: A Test of Marshall-Lerner Hypothesis." Saudi Journal of Business and Management Studies 2 (5A): 468-74. https://doi.org/10.21276/sjbms.

Rafiq, Sohrab. 2010. "Fiscal Stance, the Current Account and the Real Exchange Rate: Some Empirical Estimates from a Time-Varying Framework." Structural Change and Economic Dynamics 21 (4): 276-90. https://doi.org/10.1016/j.strueco.2010.08.003.

Shafi, Khuram, Liu Hua, Zahra Idrees, and Amna Nazeer. 2015. "Impact of Exchange Rate, Inflation Rate and Interest Rate on Balance of Payment: A Study from India and Pakistan" 3 (1): 9-13. 